\title{
Pola Pemberdayaan Narapidana
}

\author{
Hendra Fitrianto \\ Syaiful Saleh \\ Universitas Muhammadiyah Makassar \\ syaifulsaleh@unismuh.ac.id \\ Jamaluddin Arifin \\ Universitas Muhammadiyah Makassar \\ jamaluddinarifin@unismuh.ac.id
}

\begin{abstract}
ABSTRAK
Berdirinya lembaga pemasyarakatan berdasarkan pada tujuan yang jelas, yaitu untuk meningkatkan kualitas narapidana agar menyadari kesalahan yang telah diperbuatnya, sehingga kedepannya dapat memperbaiki diri serta tidak mengulangi perbuatan yang dapat merugikan masyarakat. Penelitian ini dilakukan secara kualitatif.Teknik penarikan informan menggunakan tiga metode pengumpulan data yaitu, wawancara, observasi dan dokumentasi.Metode tersebut dilakukan untuk mendapatkan data berupa pola pemberdayaan dan dampak pemberdayaan terhadap narapidana, serta hasil produksi yang diperoleh. Wawancara dilakukan terhadap seluruh pihak yang terlibat dalam program pemberdayaan narapidana.Kesemua data yang diperoleh diuji validitasnya kemudian dianalisis melalui reduksi data, penyajian data dan kesimpulan.Proses pemberdayaan yang dilakukan lebih mengedepankan pada pola dan metode langsung praktek tanpa menggunakan banyak teori. Artinya, pemberdayaan dilakukan sekaligus dengan membuat barang produksi untuk dipasarkan.Hal ini dianggap lebih mudah dipahami dan dipelajari oleh narapidana.Materi yang diberikan seputar pemberdayaan yang ada, medianya lebih banyak menggunakan alat serta bahan kerja.Partisipasi narapidana, baik keseriusan serta kedisiplinannya bisa dilihat dari keterlibatan mental, fisik, serta pikiran mereka dalam mengikuti pemberdayaan.Untuk hasilnya, berupa barang produksi yang dibuat, sesuai dengan jenis keterampilan yang dikuasai, berupa pesanan dari masyarakat maupun untuk memenuhi kebutuhan Lembaga Pemasyarakatan.
\end{abstract}

Kata Kunci : Pemberdayaan, Keterampilan, Narapidana.

\section{PENDAHULUAN}

Di era zaman yang serba modern seperti saat ini, manusia pada umumnya ada yang dapat mentaati norma-norma yang berlaku di masyarakat, ada pula yang tidak dapat menyesuaikan diri serta mentaati norma-norma tersebut dalam menjalankan kehidupannya. Akibat dari tidak memperhatikan norma-norma yang berlaku, maka tidak sedikit dari manusia yang melakukan tindakan kriminal, tindak kekerasan, peyalahgunaan obat-obat tertentu serta perilaku penyimpangan sosial yang lain. Hal ini timbul karena adanya suatu faktor yang dapat mendorong manusia melakukan tindakan-tindakan tersebut. Diantaranya adalah faktor ekonomi, budaya, politik,sikologis serta faktor biologisnya. Dengan demikian, mau tidak mau manusia yang melakukan penyimpangan norma tersebut harus berhadapan dengan penegak hukum Negara, yaitu penjara atau 
tindak pidana. Setiap warga negara memiliki hak untuk mendapatkan perlindungan dari Negara dan berhak pula untuk mengembangkan kualitas dirinya, termasuk hak atas kesempatan mengikuti pendidikan, dan disisi lain berkewajiban untuk mentaati hukum yang berlaku dan tidak menjadi gangguan bagi masyarakat, bahkan lebih jauh dituntut untuk aktif berpartisipasi dalam kegiatan pembangunan masyarakat lingkungannya. Narapidana sebagai warga Negara justru berperilaku yang merugikan masyarakat dengan perbuatan kejahatannya. Akibat kejahatan tindak pidananya itu, ia harus menerima resiko berstatus sebagai narapidana yang dipaksa mengalami penderitaan isolasi sosialnya. Namun sementara itu, ia tetap sebagai warga Negara yang memiliki hak perlindungan dari Negaranya. Atas dasar itu maka harus diperlakukan manusiawi, tidak keluar dari batas-batas hak asasi manusia. Disisi lain, tetap memiliki hak atas kesempatan memperoleh pendidikan dalam rangka mening in kualias dirinya.Semula perubahan sikap kearah yang lebih baik diharapkan dapat muncul sebagai respon dari penjeraan berupa penderitaan akibat isolasinya.Namun pengalaman menujukkan bahwa penderitaan tersebut tidak otomatis membuat narapidana menjadi jera. Cukup banyak bekas narapidana yang menjadi residivis bahkan dengan bobot kejahatan yang lebih tinggi, semuanya disebabkan oleh karena perhatian hanya ditujukan pada perbuatannya atau kejahatannya saja, sedangkan diri pelakunya sendiri kurang mendapatkan perhatian dan system pemberdayaannya yang jauh dari standar yang telah ditetapkan oleh pemerintah.

\section{LANDASAN TEORI}

Menurut Kieffer ( 1981), pemberdayaan mencakup tiga dimensi yang meliputi kompetensi kerakyatan, kemampuan sosiopolitik, dan kompetensi partisipatif (Suharto, 1997:215). Parson et.al. (1994:106) juga mengajukan tiga dimensi pemberdayaan yang merujuk pada sebuah proses pembangunan yang bermula dari pertumbuhan individual yang kemudian berkembag menjadi sebuah perubahan sosial yang lebih besar, sebuah keadaan psikologis yang ditandai oleh rasa percaya diri, berguna dan mampu mengendalikan diri dan orang lain, dan pembebasan yang dihasilkan dari sebuah gerakan sosial, yang dimulai dari pendidikan dan politisasi orang-orang lemah dan kemudian melibatkan upaya-upaya kolektif dari orang-orang lemah tersebut untuk memperoleh kekuasaan dan mengubah struktur-struktur yang masih menekan (Parsons et.al, 1994:106)

Menurut Rappaport (1987) dalam strategi pemberdayaan masyarakat, menyatakan bahwa pemberdayaan diartikan sebagai pemahaman secara psikologis 
pengaruh control individu terhadap keadaan sosial, kekuatan politik, dan hak-haknya menurut undang-undang. McArdle (1989) dalam strategi pemberdayaan masyarakat mengartikan pemberdayaan sebagai proses pengambilan keputusan oleh orang-orang yang secara konsekuen melaksanakan keputusan tersebut. Partisipasi merupakan komponen penting dalam pembangkitan kemandirian dan proses pemberdayaan (Craig dan Mayo,1995 dalam strategi pemberdayaan masyarakat).

Sistem pemasyarakatan sebagai suatu sistem perlakuan terhadap Warga binaan Pemasyarakatan selanjutnya baru memperoleh pengakuan secara yuridis formal setelah disahkannya Undang-Undang Nomor 12 Tahun 1995 Tentang Pemasyarakatan, yang mulai diundangkan pada tanggal 30 Desember 1995, Lembaran Negara Republik Indonesia Nomor 77 dan Tambahan Lembaran Negara Republik Indonesia Nomor 13641. Secara filosofis Pemasyarakatan adalah sistem pemidanaan yang sudah jauh bergerak meninggalkan filosofis retributif (pembalasan), Deterennce (penjeraan), dan resosialisasi.Lembaga Pemasyarakatan menurut Departemen Hukum dan HAM Rl adalah unit pelaksana teknis (UPT) pemasyarakatan yang menampung, merawat dan membina narapidana. Sedangkan pengertian Lembaga Pemasyarakatan menurut kamus bahasa Indonesia adalah lembaga adalah organisasi atau badan yang melakukan suatu penyelidikan atau melakukan suatu usaha. Dan pemasyarakatan adalah nama yang mencakup semua kegiatan yang keseluruhannya dibawah pimpinan dan pemilikan Departemen Hukum dan HAM, yang berkaitan dengan pertolongan bantuan atau tuntutan kepada hukuman/bekas tahanan, termasuk bekas terdakwa atau yang dalam tindak pidana diajukan ke depan pengadilan dan dinyatakan ikut terlibat, untuk kembali ke masyarakat. Para pakar mengkritik prinsip penjeraan sebagai tujuan pidana penjara. Salah satu pokok pikiran pada gagasan Sahardjo mengenai konsepsi pemasyarakatan ( R. Achmad S. Soema dipraja dan Romli atmasasmita, 1979) menyatakan bahwa tobat tidak dapat dicapai dengan penyiksaan melainkan dengan bimbingan. sosiolog Bruce L ( sahat simamora 1982 ) mengatakan bahwa sosialisasi adalah proses melalui mana manusia mempelajari tata-cara kehidupan dalam masyarakatnya untuk memperoleh kepribadian dan membangun kapasitas untuk berfungsi, baik sebagai individu maupun sebagai anggota kelompok.

\section{METODE PENELITIAN}

Jenis penelitian yang dilakukan penelitian kualitatif yang bertujuan mengetahui pola pemberdayaan Narapidana yang diberikan oleh petugas Lembaga Pemasyarakatan 
kelas I Makassar. Subyek penelitian yaitu Kepala Lembaga Pemasyarakatan kelas I Makassar, kepala pemberdayaan beserta staff Lembaga Pemasyarakatan kelas I Makassar, Narapidana Lembaga Pemasyarakatan kelas I Makassar. Teknik pengumpulan data yaitu observasi, wawancara dan dokumentasi, kemudian dianalisis melalui tahapan pengumpulan data, reduksi data, penyajian data, penarikan kesimpulan dan menggunakan teknik keabsahan data triangulasi sumber, waktu dan teknik.

\section{PEMBAHASAN}

Dalam membentuk narapidna akan sadar dengan kesalahannya serta mau memperbaikinya tentu memerlukan proses yang tidak mudah. Sehinggah banyak sekali Lembaga Pemasyarakatan yang melakukan pemberdayaan maupun pembinaan, khususnya Lembaga Pemasyarakatan kelas I Makassar.Pemberdayaan sebagai gerakan sosial pada umumnya dimaksudkan untuk mendorong dan mempercepat terjadinya transformasi nilai bahkan transformasi struktural dalam masyarakat.Oleh sebab itu, pemberdayaan atau gerakan sosial diharapkan mempercepat proses reorientasi berdasarkan nilai-nilai yang terkandung dalam perspektif baru. Proses pemberdayaan diharapkan mampu menghasilkan perubahan pada sumber daya, proses pengambilan keputusan atau kewenangan, dan peningkatan kapasitas untuk menunjang masa depan. Oleh karena itu, narapidana juga membutuhkan pemberdayaan untuk menunjang masa depannya ketika selesai menjalani masa hukumannya.

Pemberdayaan sebagai suatu proses adalah suatu kegiatan yang berkesinambungan sepanjang manusia itu masih ingin melakukan perubahan dan perbaikan yang tidak hanya terpaku suatu program saja. Melihat proses pemberdayaan sebagai suatu proses yang relatif terus berjalan sepanjang usia manusia yang diperoleh dari pengalaman individu tersebut dan bukan suatu proses yang berhenti di suatu masa.Lembaga Pemasyarakatan ingin menciptakan narapidana yang memiliki keterampilan setelah keluar dari Lembaga Pemasyarakatan.Tujuannya adalah setelah keluar dari Lembaga Pemasyarakatan narapidana bisa menjalani hidupnya dan diterima ditengah-tengah masyarakat dengan harapan tidak melakukan tindakan kriminal.Ikhtiar dilaksanakan selain merupakan amanah konstitusi, juga merupakan usaha sadar yang dilakukan dengan sungguh-sungguh dalam membantu para narapidana untuk dapat kembali menemukan arti pentingnya hidup rukun dan damai dalam bermasyarakat, berbangsa dan bernegara.Selain pembinaan kepribadian dan kerohanian, bimbingan untuk menciptkan usaha sendiri juga diberikan.Hal ini dilakukan, mengingat persoalan 
ekonomi, seperti kemiskinan, pengangguran adalah merupakan factor yang kerap menjadi simultan bagi seseorang atau sekelompok masyarakat untuk melakukan kejahatan atau tindak pidana.Usaha ini sebagai langkah pemberdayaan kepada warga binaan di Lembaga Pemasyarakata Kelas I Makassar agar memiliki ketarampilan sebagai salah satu indikator keberhasilan pembinaan kemandirian yang merupakan bentuk peningkatan sumberdaya manusia bagi narapidana. Pembinaan Kemandirian tersebut meliputi:

a. Keterampilan untuk usaha-usaha mandiri seperti, kursus potong rambut, kursus menjahit dan sablon.

b. Keterampilan yang dikembangan sesuai bakatnya, misalnya pengolahan bahan mentah menuju bahan setngah jadi dan bahan jadi. Contoh, membuat mebeler keset, matras dari sabut kelapa.

c. Keterampilan untuk mendukung usah-usaha industry sesuai bakat seninya masingmasing, misalnya seni lukis, seni ukir kayu, bantalan mesin diesel, pembuatan mesin sabut kelapa, pembuatan tempe, pembuatan kursi bambu, keterampilan anyaman bambu, tutup bosara dan miniature perahu finisi.

d. Pengembangan keterampilan pertukangan untuk membuat kursi kayu, meja kayu.

e. Perikanan air tawar, pembibitan ikan hias, pembuatan Faving Blok dan tanaman hias.

Konsep pemberdayaan dalam wacana pembangunan masyarakat/Narapidana selalu dihubungkan dengan konsep mandiri, partisipasi, jaringan kerja, dan keadilan.Pada dasarnya, pemberdayaan diletakkan pada kekuatan tingkat individu dan sosial.Menurut Rappaport (1987) dalam strategi pemberdayaan masyarakat, menyatakan bahwa pemberdayaan diartikan sebagai pemahaman secara psikologis pengaruh control individu terhadap keadaan sosial, kekuatan politik, dan hak-haknya menurut undangundang.Artinya, proses pemberdayaan yang dilakukan oleh Lembaga Pemasyarakatan kelas I Makassar merupakan salah satu strategi untuk membentuk kemampuan berfikir serta bertanggung jawab untuk mengerjakan sesuatu secara efektif dan benar. Dengan demikian dapat menjadikan narapidana memiliki masa depan yang terarah. Diantaranya adalah menjadikan narapidana menjadi tenaga kerja yang terampil dalam berwiraswasta atau mengisi lowongan pekerjaan yang ada setelah keluar dari Lembaga Pemasyarakatan, melatih kemandirian dapat meningkatkan atau mengisi kegiatan latihan pemberdayaan yang sudah ada di lingkungan masyarakat, dapat memberikan bekal percaya diri serta merasa terhormat di lingkungan sekitarnya serta dapat menafkahi kembali keluarga khususnya yang sudah berkeluarga. 
Lembaga Pemasyarakatan tidak melakukan tindak pemaksaan terhadap narapidana untuk ikut dalam pemberdayaan, tetapi tergantung dari keinginan narapidana. Namun tidak semua narapidana ikut serta dalam kegiatan pemberdayaan, karena dari hasil wawancara penulis terhadap petugas Lembaga Pemasyarakatan ternyata ada beberapa mekanisme Lembaga Pemasyarakatan dalam merekrut narapidana untuk di berdayakan.Lembaga pemasyarakatan Kelas I Makassar merupakan unit pelaksana teknis pemasyarakatan yang menampung, merawat, membina warga binaan ( Narapidana). Agar dapat melaksanakan tugas-tugas tersebut maka petugas pemasyarakatan selayaknya harus memahami mekanisme kerja sesuai dengan bidangnya masing-masing, sehingga dapat menjalankan tugasnya dengan penuh tanggung jawab.Setelah petugas Lembaga Pemasyarakatan melakukan perekrutan narapidana untuk ikut dalam kegiatan pemberdayaan, petugas akan mengontrol dan membimbing narapidana dalam proses pemberdayaan berlangsung. Kemudian setelah itu, narapidana diberikan kebebasan untuk melakukan atau mengembangkan potensi yang dimilikinya.Selain narapidana diberdayakan di Lembaga Pemasyarakatan, narapidana juga ikut diperbantukan untuk melayani atau melakukan kegiatan pegawai. Petugas Lembaga Pemasyarakatan Kelas I Makassar memberikan empat pola pemberdayaan terhadap narapidana, diantaranya sebagai berikut:

1. Esesmen (Penggalian Potensi) merupakan sebuah pola pemberdayaan terhadap narapidana dengan orientasi untuk melacak dan mengetahui potensi atau skill yang dimiliki seorang narapidana

2. Pelatihan teknis aplikatif. Pelatihan ini merupakan pola yang diterapkan dalam rangka memudahkan narapidana mengembangkan skill dan kemampuannya secara praktis dan cepat tanpa menggunakan teori-teori lazimnya dalam sebuah sekolah dan perguruan tinggi.

3. Mengelola pekerjaan berdasarkan sumber daya warga binaan yang sudah di petakan.

4. Hasil kerja dan insentif hasil produksi.

Proses pemberdayaan pada Lembaga Pemsyarakatan Kelas I Makassar sangat dinamis dan berkesinambungan. Proses pembinanaan dan bimbingan bagi para narapidana merupakan upaya perlindungan terhadap warga binaan (Narapidana) agar mereka kembali diterima dengan tangan terbuka ke tengah-tengah masyarakat, selain menyadari dan menginsyafi kesalahan yang telah diperbuatnya juga dapat mandiri tidak tergantung pada orang lain.Pemberdayaan telah memberikan dampak yang sangat positif terhadap narapidana.Dimana lembaga pemasyarakatan memberikan fasilitas kerja 
walaupun masih sangat terbatas. Adapun beberapa dampak positif yang di katakan oleh narapidana pada saat penulis melakukan wawancara adalah sebagai berikut:

1. Menghilangkan rasa jenuh

Kehidupan sehari-hari para narapidana di berikan batas gerak dalam melakukan aktivitas, oleh karena itu narapidana masing-masing melakukan kesibukan tiap harinya untuk menghilangkan rasa jenuh.Salah satu kegiatan untuk bisa menghilangkan rasa jenuh para narapidana agar tidak putus asa dalam menjalani hidup adalah ikut dalam kegiatan pemberdayaan.

2. Mendapatkan keahlian dalam bekerja

Kegiatan pemberdayaan mereka sangatlah merasa senang dan bersyukur mengikuti kegiatan pemberdayaan karena petugas Lembaga Pemasyarakatan memberikan bimbingan dan pembinaan terhadap narapidana serta kebebasan dalam bekerja untuk dapat menguasai teknik dalam mengerjakan sesuatu. Keahlian inilah yang akan menjadi bekal besar bagi para narapidana untuk dapat melakukan aktifitas yang positif agar dapat mandiri nantinya setelah keluar dari Lembaga Pemsyarakatan.

3. Dapat menafkahi keluarga

Lembaga Pemasyarakatan adalah sebuah wadah di mana para narapidana diberikan pembinaan dan di berdayakan.Walaupun narapidana di batasi ruang geraknya dalam kehidupan sehari-harinya namun mereka harus tetap dapat menafkahi keluarganya.

\section{Kesadaran Hukum}

Melalui proses pemberdayaan yang berikan, narapidana dapat menyadari betapa pentingnya menaati norma-norma yang berlaku di tengah-tengah masyarakat dan hukum yang berlaku di Indonesia.

\section{Etos Kerja}

Melalui pemberdayaan yang dilakukan secara kolektif kolegia dan berkesinambungan, disipli, tertib dan penuh semangat tinggi, narapidana dapat meningkatkat etos kerjanya.

\section{KESIMPULAN}

1. Proses pemberdayaan yang dilakukan oleh petugas Lembaga Pemasyarakatan kelas I Makassar, mencakup pola pemberdayaan, metode pemberdayaan, materi pemberdayaan, serta media pemberdayaan. Pola pemberdayaan merupakan rencana rangkaian kegiatan yang meliputi, peserta, persiapan, pelaksanaan, evaluasi. Metode pemberdayaan merupakan serangkaian kegiatan pemberdayaan yang dilakukan oleh 
petugas Lembaga Pemasyarakatan kelas I Makassar untuk mewujudkan pola yang sudah dibuat meliputi berupa apel dan persiapan peralatan kerja, pelaksanaan berupa bimbingan dan pengarahan pembuatan barang produksi, serta evaluasi berupa pencatatan barang jadi. Materi pemberdayaan langsung diperoleh dari pembimbing yang sudah ahli di bidangnya. Sedangkan untuk media berupa sarana prasarana peralatan dan bahan kerja, gambar dan buku-buku keterampilan. Proses pemberdayaan ini bertujuan untuk memberikan keahlian dalam bekerja agar narapidana memiliki bekal setelah keluar dari Lembaga Pemasyarakatan.

2. Partisipasi yang ditunjukkan oleh narapidana yang tergabung dalam kegiatan pemberdayaan meliputi keseriusan dan kedisiplinan. Keseriusan bisa dilihat dari keterlibatan secara fisik, mental dan pikiran. Sedangkan kedisiplinan yang ditunjukkan berupa menjalankan dan mentaati tata tertib yang sudah dibuat selama mengikuti kegiatan kerja.

3. Hasil pemberdayaan meliputi jenis keterampilan yang dikuasai oleh masing-masing narapidana serta produksi barang yang di peroleh. Masing-masing narapidana memilih jenis keterampilan yang di minati dan ingin di dalami. Dari hasil produksi barangnya mereka bisa mendapatkan upah.

\section{DAFTAR PUSTAKA}

Anonim, Defenisi Tahanan dan Narapidana di Lembaga Pemasyarakatan atau Lapas, http://www.hukumonline.com di akses pada tanggal 8 Januari 2015 pukul 09.32 .

Dahlan, M.Y. AI-Barry, ,(2003).Kamus Induk Istilah llmiah Seri Intelectual, Surabaya, Target Press.

Departemen Pendidikan dan Kebudayaan.(1994) Kamus Besar Bahasa Indonesia Edisi Kedua. Balai Pustaka. Jakarta.

Dwidja Priyanto, (2006). Sistem Pelaksanaan Pidana Penjara Di Indonesia, Refika Aditama, Bandung.

Edi Suharto,Ph.D. (2010). Membangun Masyarakat Memberdayakan Rakyat, Refika Aditama, Bandung

Hamzah, Andi.(1994). Sistem Pidana dan Pemidanaan Indonesia Dari Retribusi di Reformasi, Pradaya Paramita, Jakarta.

Hikmat Harry, (2013). Strategi Pemberdayaan Masyarakat. Humaniora Utama Press, Bandung.. 
Kanter E.Y \& S.R. Sianturi.(2002) .Azas-Azas Hukum Pidana Di Indonesia Dan Penerapannya. Storia Grafika. Jakarta.

Moleong J Lexy, (2011), Metode Penelitian Kualitatif, Bandung. PT.Remaja Rosdakarya.

Panjaitan dan Simorangkir, (1995).LAPAS Dalam Prespektif Sistem Peradilan Pidana, Jakarta, Pustaka Sinar harapan.

Parson et.al.Pemberdayaan Masyarakat, 1994

Peraturan Pemerintah Nomor 31 Tahun 1999 tentang Pembinaan dan Pembimbingan Warga Binaan Pemasyarakatan.

Reglemen Penjara (Staatsblad 708 Tahun 1917)

Azharul Hikmah, Profil Narapidana di Lembaga Pemasyarakatan Wirogunan Yogyakarta (Studi Terhadap Narapidana Wanita).

Nasher Sholahuddin, Peran Lembaga Pemasyarakatan Wirogunan Yogyakarta Dalam Pemberdayaan Narapidana.

Slamet, Yulius, 2006, Metode Penelitian Sosial, Surakarta.

Soeratno, (1995) .Metode Penelitian, Yogyakarta: UUP AMP YKPN,

Soetomo.Pemberdayaan Masyarakat, Pustaka Pelajar. Yogyakarta.

Sutopo.HB, (2002), Metode Penelitian Sosial, Surakarta.

Undang - Undang Nomor 12 Tahun 1995 tentang Pemasyarakatan. 